\title{
Pirarubicin, an Anthracycline Anticancer Agent, Induces Apoptosis Through Generation of Hydrogen Peroxide
}

\author{
HIDEKI MIZUTANI $^{1}$, SAKI HOTTA ${ }^{1}$, AYANO NISHIMOTO ${ }^{1}$, KENJI IKEMURA $^{1,2}$, DAISUKE MIYAZAWA ${ }^{1}$, \\ YOSHIAKI IKEDA ${ }^{1}$, TOHRU MAEDA ${ }^{1}$, MASAE YOSHIKAWA ${ }^{1}$, YUSUKE HIRAKU ${ }^{3}$ and SHOSUKE KAWANISHI ${ }^{4}$ \\ ${ }^{1}$ College of Pharmacy, Kinjo Gakuin University, Nagoya, Japan; \\ ${ }^{2}$ Department of Pharmacy, Mie University Hospital, Tsu, Japan; \\ ${ }^{3}$ Department of Environmental and Molecular Medicine, Mie University Graduate School of Medicine, Tsu, Japan; \\ ${ }^{4}$ Faculty of Pharmaceutical Sciences, Suzuka University of Medical Science, Suzuka, Japan
}

\begin{abstract}
Background/Aim: Pirarubicin (THP) has shown equal or superior cytotoxicity compared to doxorubicin. One of the main anticancer actions of doxorubicin is believed to be involved in ROS (reactive oxygen species) generation. Therefore, the anticancer mechanisms of THP may involve ROS generation. The aim of this study was to clarify the mechanisms of THP-induced apoptosis through ROS generation. Materials and Methods: We analyzed the apoptotic events induced by THP in $\mathrm{HL}-60$ cells and HP10O cells, hydrogen peroxide $\left(\mathrm{H}_{2} \mathrm{O}_{2}\right)$ resistant cells derived from $H L-60$. Results: The apparent cytotoxicity could be detected at above $0.1 \mu \mathrm{M}$ in HL-60 cells after 24-h incubation, whereas it was suppressed under these conditions in HP100 cells. In HP100 cells, THP-induced apoptosis, evaluated by DNA ladder formation, $\mathrm{H}_{2} \mathrm{O}_{2}$ generation, mitochondrial membrane potential decrease and caspase-3/7 activity, was suppressed or delayed compared to those of HL-60 cells. Conclusion: These findings can be explained by the involvement of $\mathrm{H}_{2} \mathrm{O}_{2}$ generation in the THP apoptotic pathway. This is the first report on THP-induced apoptosis through the $\mathrm{H}_{2} \mathrm{O}_{2}$ generation.
\end{abstract}

Anthracyclines are anticancer drugs and are the most important drug categories in clinical usage. Doxorubicin (Figure 1), an anthracycline drug, shows potent effects on solid cancers as well as hematological malignancies (1-3).

This article is freely accessible online.

Correspondence to: Hideki Mizutani, Ph.D., College of Pharmacy, Kinjo Gakuin University, Moriyama-ku, Nagoya 463-8521, Japan. Tel: +81 527987458, Fax: +81 527980754, e-mail: mizu@kinjou.ac.jp and Shosuke Kawanishi, Ph.D., Faculty of Pharmaceutical Sciences, Suzuka University of Medical Science, Suzuka, Mie 5138670, Japan. Tel: +81 593400568, Fax: +81 593681271, e-mail: kawanisi@suzuka-u.ac.jp

Key Words: Pirarubicin, apoptosis, hydrogen peroxide, ROS.
Pirarubicin (4'-O-tetrahydropyranyl doxorubicin, THP) (Figure 1), a tetrahydropyranyl-derivative doxorubicin, was found and developed by Umezawa et al. in 1979 (4). THP showed equal or superior cytotoxicity in cultured tumor cells, and less cardiotoxicity in hamsters compared to DOX $(5,6)$. THP is incorporated into cells about 170-times rapider than DOX in cultured tumor cells $(5,7)$. THP is clinically approved for head and neck cancer, stomach cancer, upper urinary tract cancer, uterus cancer, ovarian cancer, acute leukemia and malignant lymphoma in Japan. Recently, Hori et al. reported that THP appeared to be less cardiotoxic than daunorubicin on acute and late toxicities in the treatment of childhood acute lymphoblastic leukemia on a clinical trial by the Japan Association of Childhood Leukemia Study (8). On the other hand, THP has attracted increasing attention, because THP-DDS (drug delivery systems) developed by Maeda et al. have high tumortargeting efficiency by EPR (enhanced permeability and retention) effect $(9,10)$. Maeda and his collaborators were also successful at treating the THP-DDS (HPMA copolymer-conjugated pirarubicin) for a patient with stage IV prostate cancer and extensive lung and bone metastases (11). Therefore, THP has once more attrected attention in the field of cancer chemotherapy.

Anthracyclines generate ROS (reactive oxygen species) causing oxidative DNA damage that may be one of THP anticancer mechanisms (1-3). ROS also play an important role in cell signaling as well as in anticancer mechanisms (12-14), whereas the role of ROS in THP anticancer mechanisms remains to be clarified and is not reported. To clarify THP anticancer mechanisms, we investigated the mechanism of THP-induced apoptosis in HL-60 cells and HP100 cells, hydrogen peroxide $\left(\mathrm{H}_{2} \mathrm{O}_{2}\right)$-resistant cells derived from HL-60. The mechanism of apoptosis was analyzed by examining cytotoxicity, DNA ladder formation, $\mathrm{H}_{2} \mathrm{O}_{2}$ generation, mitochondrial membrane potential $(\Delta \Psi \mathrm{m})$ change and caspase- $3 / 7$ activity. 
<smiles>COc1cccc2c1C(=O)c1c(O)c3c(c(O)c1C2=O)CC(O)(C(=O)OCO)CC31CC2OC3CCCCO[C@@H]3CC(C[C@H]2N)O1</smiles>

Pirarubicin (THP)<smiles>COc1cccc2c1C(=O)c1c(O)c3c(c(O)c1C2=O)CC(O)(C(=O)O)CC3OC1CC(N)[C@H](N)C[C@H]1O</smiles>

Doxorubicin (DOX)

Figure 1. Chemical structure of pirarubicin and doxorubicin.

A : $6 \mathrm{~h}$

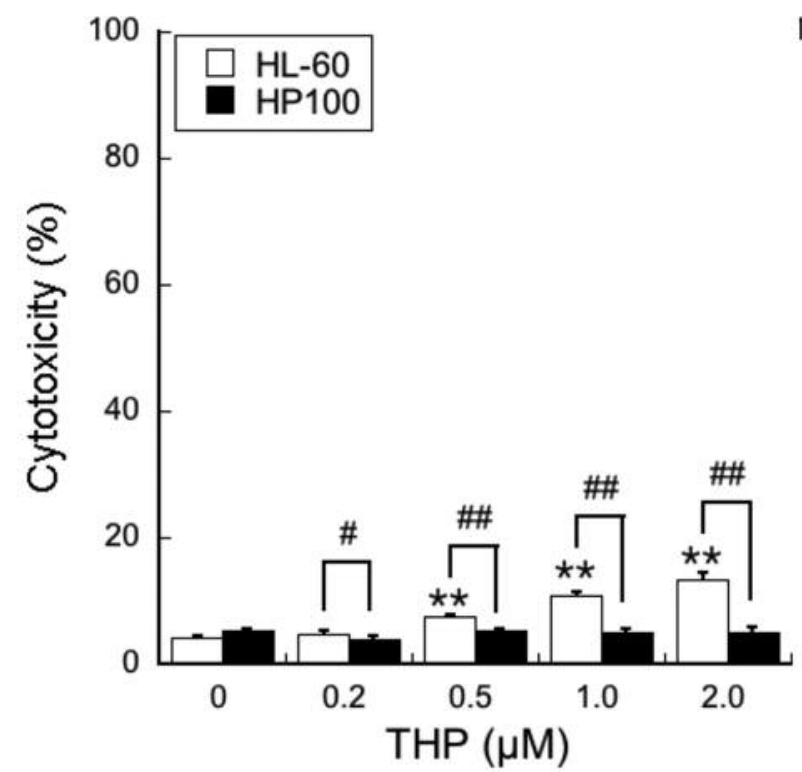

$B: 24 \mathrm{~h}$

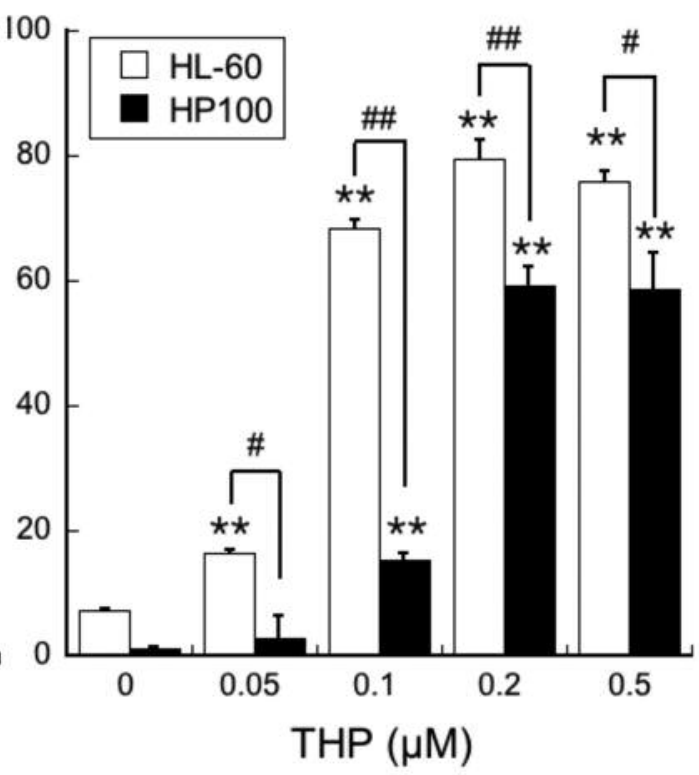

Figure 2. Detection of cytotoxicity in HL-60 and HP100 cells treated with THP. HL-60 and HP100 cells $\left(0.5 \times 10^{6}\right.$ cells $\left./ \mathrm{ml}\right)$ were treated with THP at $37^{\circ} \mathrm{C}$ for $6 \mathrm{~h}(\mathrm{~A})$ and $24 \mathrm{~h}(\mathrm{~B})$. After treatment with THP, cytotoxicity was analyzed by the LDH activity assay kit (CytoTox-ONE ${ }^{T M}$ Homogeneous Membrane Integrity Assay, Promega) according to the manufacturer's instructions. The data were expressed as means $\pm S D(n=3)$. ** $p<0.01, v s$. control by ANOVA followed by Tukey's HSD test; ${ }^{\#} p<0.05$ and ${ }^{\# \#} p<0.01$, HL-60 vs. HP100 by the Student's t-test.

\section{Materials and Methods}

Materials. Pirarubicin was purchased from Sigma Chemical Co. (St. Louis, MO, USA). Proteinase K was obtained from Merck (Darmstadt, Germany). Fluorescent probes, 2',7'-Dichlorofluorescin diacetate (DCFH-DA) and 3,3'-dihexyloxacarbocyanine iodide $\left[\mathrm{DiOC}_{6}(3)\right]$ were purchased from Molecular Probes (Eugene, OR, USA). All other chemicals used were of the highest purity commercially available.
Cell culture and treatment with THP. HP100 cells have been derived from human leukemia HL-60 cells by repeated exposure to $\mathrm{H}_{2} \mathrm{O}_{2}$, followed by outgrowth of viable cells. HP100 cells were approximately 340 -fold more resistant to $\mathrm{H}_{2} \mathrm{O}_{2}$ than HL-60 cells (15). Catalase activity of HP100 cells is 18 -times higher than that of HL-60 cells (16). When scavengers such as catalase, superoxide dismutase and reduced glutathione are added in cell culture medium, these scavengers exist in the extracellular environment $(17,18)$. 
Therefore, the effects of the scavengers are not evaluated correctly On the other hand, the increased catalase of HP100 cells exist in the intracellular components, thus the effects of catalase can be evaluated correctly. HL-60 and HP100 cells were grown in RPMI 1640 supplemented with $6 \% \mathrm{FBS}$ at $37^{\circ} \mathrm{C}$ under $5 \% \mathrm{CO}_{2}$ in a humidified atmosphere. The cells $\left(0.5 \times 10^{6}\right.$ or $1 \times 10^{6}$ cells $\left./ \mathrm{ml}\right)$ were then treated with the indicated concentrations of THP.

Determination of cytotoxicity induced by THP in HL-60 and HP100 cells. A lactate dehydrogenase (LDH) activity assay kit (CytoTox$\mathrm{ONE}^{\mathrm{TM}}$ Homogeneous Membrane Integrity Assay, Promega, USA) was used to measure cytotoxicity in cultures. $5 \times 10^{4}$ cells were seeded into each well of 96 -well culture plates. After the treatment with THP for 6 or $24 \mathrm{~h}$, cytotoxicity was analyzed according to the manufacturer's instructions (19).

Detection of apoptosis induced by THP in HL-60 and HP100 cells. For analyses of DNA ladder formation after the cells were treated with THP, cells were washed twice with PBS. Cells $\left(2 \times 10^{6}\right.$ cells $)$, resuspended in $1 \mathrm{ml}$ cytoplasm extraction buffer [10 $\mathrm{mM}$ Tris $(\mathrm{pH}$ 7.5), $150 \mathrm{mM} \mathrm{NaCl}, 5 \mathrm{mM} \mathrm{MgCl}{ }_{2}$ and $0.5 \%$ Triton $\left.\mathrm{X}-100\right]$, were centrifuged at $1,000 \times \mathrm{g}$ for $5 \mathrm{~min}$ at $4^{\circ} \mathrm{C}$. The pellet was resuspended in lysis buffer [10 mM Tris $(\mathrm{pH} 7.5), 400 \mathrm{mM} \mathrm{NaCl}$ and $1 \mathrm{mM}$ EDTA] and centrifuged at $12,000 \times \mathrm{g}$ for $10 \mathrm{~min}$ at $4^{\circ} \mathrm{C}$. The supernatant was then treated with $0.2 \mathrm{mg} / \mathrm{ml}$ RNase overnight at room temperature, followed by treatment with proteinase $\mathrm{K}$ as described previously (20). DNA ladder formation was analyzed by conventional electrophoresis.

Imaging cytometric analysis of peroxide generation and $\Delta \Psi_{m}$ change in cells treated with THP. HL-60 and HP100 cells $\left(1 \times 10^{6}\right.$ cells $/ \mathrm{ml}$ ) were treated with THP at $37^{\circ} \mathrm{C}$ for the indicated times. After the treatment, the cells were incubated with $5 \mu \mathrm{M}$ DCFH-DA for $30 \mathrm{~min}$ (peroxide generation) or $40 \mathrm{nM} \mathrm{DiOC}_{6}(3)$ for $15 \mathrm{~min}$ $(\Delta \Psi \mathrm{m})$ at $37^{\circ} \mathrm{C}$. Cells were then washed twice with PBS. Following resuspension in PBS, the cells were analyzed on an imaging cytometer (Tali ${ }^{\mathrm{TM}}$ Image-based Cytometer; Invitrogen, USA). Dead cells and debris were excluded from the analysis by cell sizes (21).

Caspase-3/7 analysis of apoptosis induced by THP in HL-60 and HP100 cells. A caspase-3/7 activity assay kit (Apo-ONE ${ }^{\circledR}$ Homogeneous Caspase-3/7 Assay, Promega, USA) was used to measure caspase-3/7 activity in cultures. $5.0 \times 10^{4}$ cells were seeded into each well of 96-well culture plates. After the treatment with THP for $24 \mathrm{~h}$, caspase-3/7 activity was analyzed according to the manufacturer's instructions.

\section{Results}

Cytotoxicity in HL-60 and HP100 cells induced by THP. We determined cytotoxicity in the cells treated with THP using an LDH release assay. As observed in Figure 2A and B, HL60 cells were more sensitive to THP in comparison to HP100 cells at 6 -h and 24-h incubation $(p<0.05)$. At $6 \mathrm{~h}$, THP induced significant cytotoxicity at $0.5,1.0$ and $2.0 \mu \mathrm{M}$ in HL-60 $(p<0.01)$, but not in HP100 cells. The cytotoxicity of THP for 24-h incubation was higher than that of THP for 6$\mathrm{h}$ incubation. The cytotoxicity at $0.1 \mu \mathrm{M}$ THP for $24-\mathrm{h}$ incubation was about $68 \%$ in HL-60 cells, whereas that was
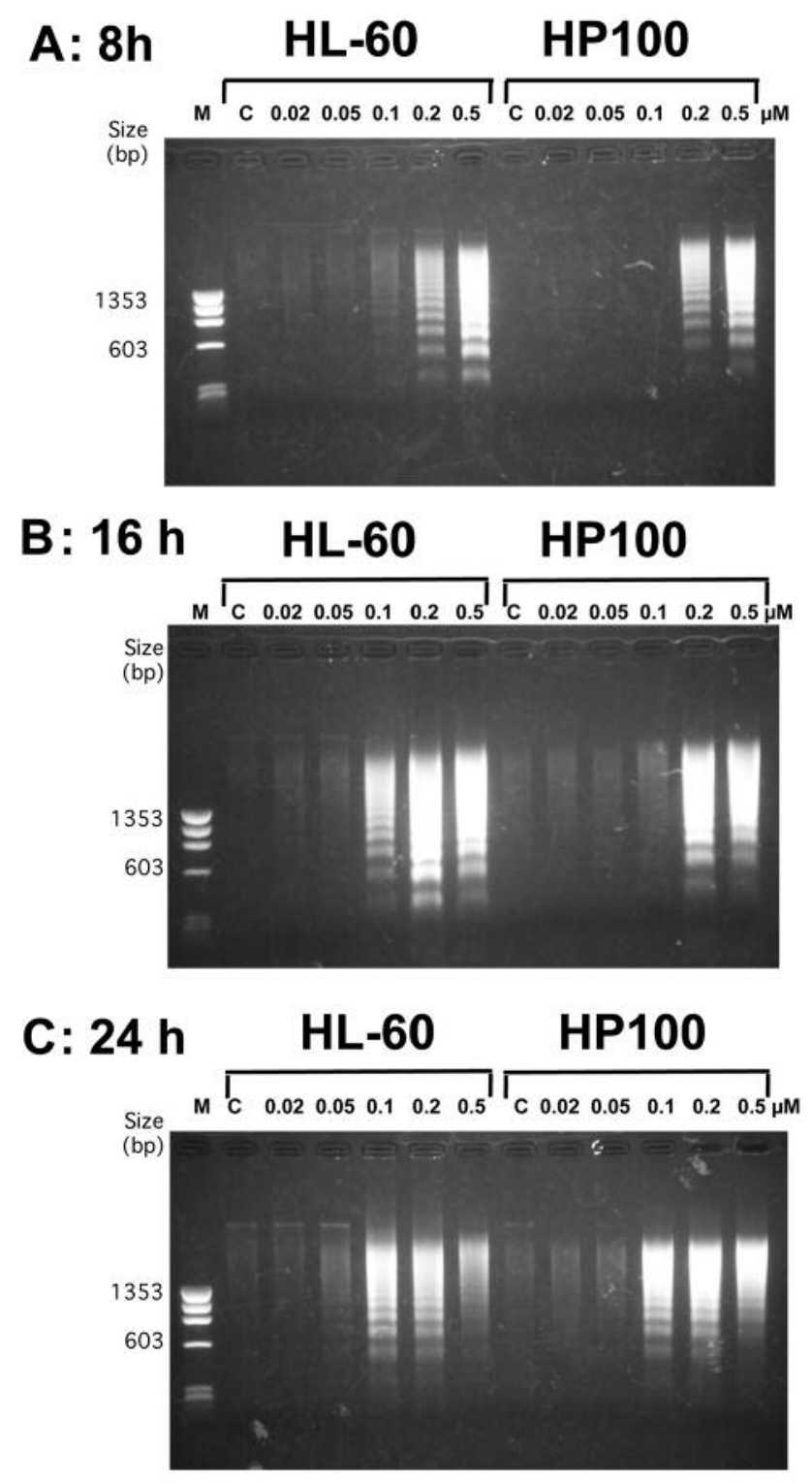

Figure 3. Detection of DNA ladder formation in HL-60 and HP100 cells treated with THP. HL-60 and HP100 cells $\left(0.5 \times 10^{6}\right.$ cells $\left./ \mathrm{ml}\right)$ were treated with THP at $37^{\circ} \mathrm{C}$ for $8 h(A), 16 h(B)$ and $24 h(C)$. The cells were lysed, and DNA was extracted and analyzed by conventional electrophoresis. Marker lane: size marker DNA (ФX174/Hae III digest).

only approximately $15 \%$ in HP100 cells. Therefore, HL-60 cells were about 4.5-fold sensitive to THP than HP100 cells at $0.1 \mu \mathrm{M}$ THP for $24-\mathrm{h}$ incubation.

DNA ladder formation in HL-60 and HP100 cells treated with THP. We have analyzed DNA ladder formation, which is characteristic for apoptosis, in the cells treated with THP using conventional electrophoresis (Figure 3). The DNA 


\section{$A: \mathrm{H}_{2} \mathrm{O}_{2} 3 \mathrm{~h} \quad \mathrm{~B}: \mathrm{H}_{2} \mathrm{O}_{2} 6 \mathrm{~h}$}
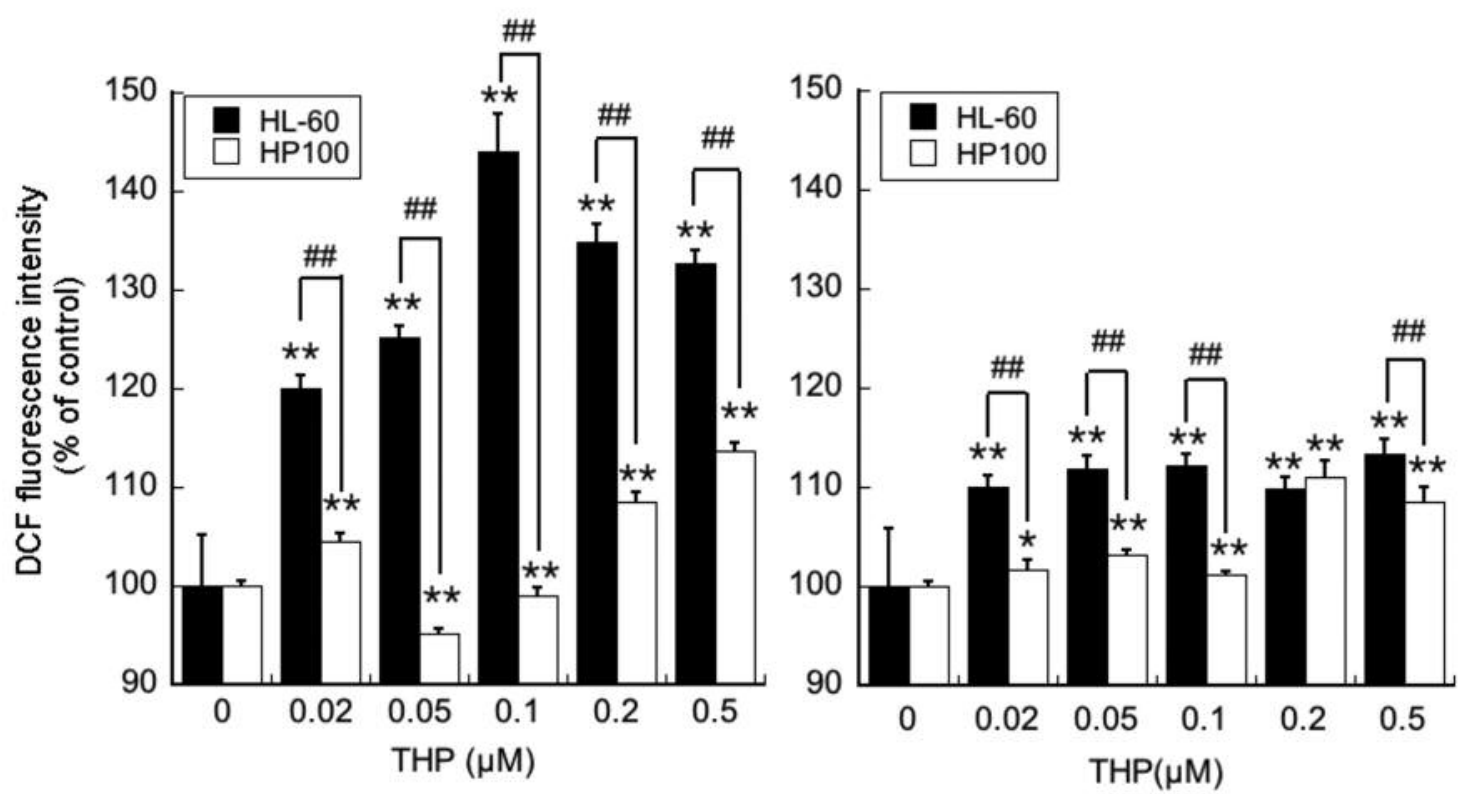

Figure 4. Generation of $\mathrm{H}_{2} \mathrm{O}_{2}$ in $\mathrm{HL}-60$ and $\mathrm{HP} 100$ cells treated with THP. $\mathrm{HL}-60$ and $\mathrm{HP} 100$ cells $\left(1 \times 10^{6} \mathrm{cells} / \mathrm{ml}\right)$ were treated with $\mathrm{THP}$ at $37^{\circ} \mathrm{C}$ for $3 h(A)$ and $6 h(B)$. After the treatment, the cells were incubated with $5 \mu M D C F H-D A$ for 30 min at $37^{\circ} C$. The cells were analyzed with an imaging cytometer (Tali ${ }^{T M}$ Image-based Cytometer; Invitrogen, USA). The data were expressed as means $\pm S D$ ( $n=9$ capture fields). ${ }^{*} p<0.05$ and ${ }^{* *} p<0.01$, vs. control by ANOVA followed by Tukey's HSD test; ${ }^{* \#} p<0.01$, HL-60 vs. HP100 by the Student's t-test.

ladder formation by THP could be detected at 0.2 and 0.5 $\mu \mathrm{M}$ in HL-60 and HP100 cells after 8-h incubation (Figure $3 \mathrm{~A}$ ), and it could be detected at $0.1,0.2$ and $0.5 \mu \mathrm{M}$ in HL60 and HP100 cells after 24-h incubation (Figure 3C). After 16-h incubation, the DNA ladder by THP could be detected at $0.1,0.2$ and $0.5 \mu \mathrm{M}$ in HL-60 cells, whereas it could not be detected at $0.1 \mu \mathrm{M}$ in HP100 cells (Figure 3B). On the other hand, after 6-h incubation, the DNA ladder by THP could not be detected at in both HL-60 and HP100 cells (data not shown).

Generation of peroxide and change of $\Delta \Psi_{m}$ in $H L-60$ and HP100 cells treated with THP. As shown in Figures 4A and B, peroxide generation in HL-60 and HP100 cells was observed at 3 and $6 \mathrm{~h}$. The peroxide generation in HL-60 cells remarkably increased at $3 \mathrm{~h}$ after the treatment with THP $(p<0.01)$, whereas its generation in HP100 cells was significantly suppressed at 3 and $6 \mathrm{~h}$ compared with HL-60 cells $(p<0.01)$. These results indicate that the THP-induced peroxide is mainly $\mathrm{H}_{2} \mathrm{O}_{2}$, because catalase activity in HP100 cells is much higher than that in HL-60 cells (16). Figure 5A and B show change of $\Delta \Psi \mathrm{m}$ in HL-60 and HP100 cells treated with THP. $\Delta \Psi \mathrm{m}$ was apparently decreased at above
$0.05 \mu \mathrm{M}$ THP in HL-60 and HP100 cells at 16-h incubation $(p<0.01)$, whereas the decrease of $\Delta \Psi \mathrm{m}$ in HP100 cells was significantly suppressed in comparison with HL-60 cells at above $0.2 \mu \mathrm{M}$ THP $(p<0.01)$.

Assessment of THP-induced apoptosis by caspase-3/7 activity in HL-60 and HP100 cells. We assessed THPinduced apoptosis by activation of caspase-3/7. The activation of caspase-3/7 in THP-treated cells was measured using a caspase-3/7 activity assay kit at $24-\mathrm{h}$ incubation. The caspase-3/7 activity was remarkably increased in treatment with THP at above $0.1 \mu \mathrm{M}$ in HL-60 and HP100 cells $(p<0.001)$. Caspase-3/7 activity in HL-60 was significantly higher than that observed in HP100 at $0.1,0.2$ and $0.5 \mu \mathrm{M}$ (Figure 6) $(p<0.05)$.

\section{Discussion}

The present study showed that THP induced apoptosis in both HL-60 cells and the $\mathrm{H}_{2} \mathrm{O}_{2}$-resistant clone, HP100 cells. The apparent cytotoxicity could be detected at above $0.1 \mu \mathrm{M}$ in HL-60 cells after 24-h incubation, whereas it was suppressed under these conditions in HP100 cells. The 
A : $\Delta \Psi \mathrm{m} 6 \mathrm{~h}$

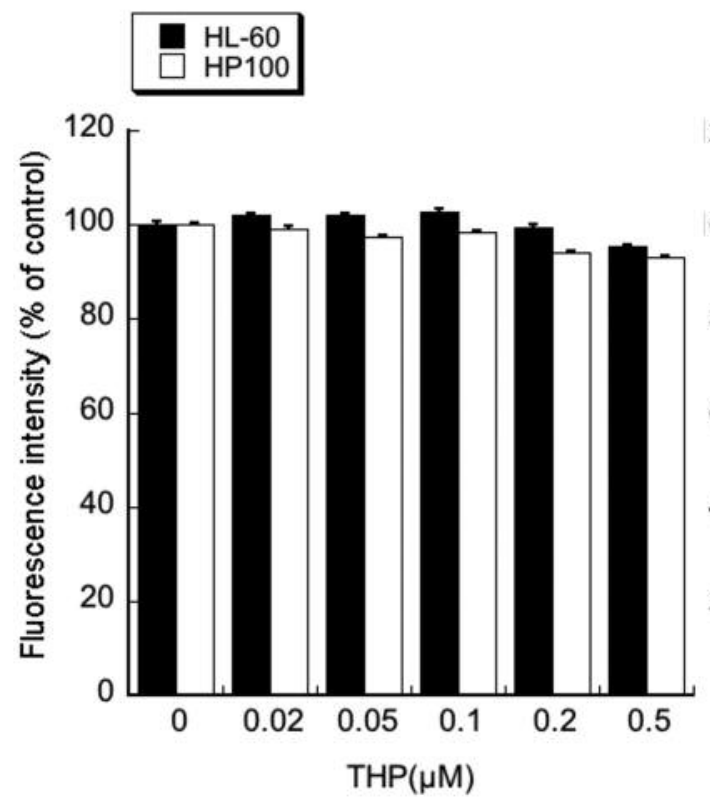

$\mathrm{B}: \Delta \Psi \mathrm{m} 16 \mathrm{~h}$

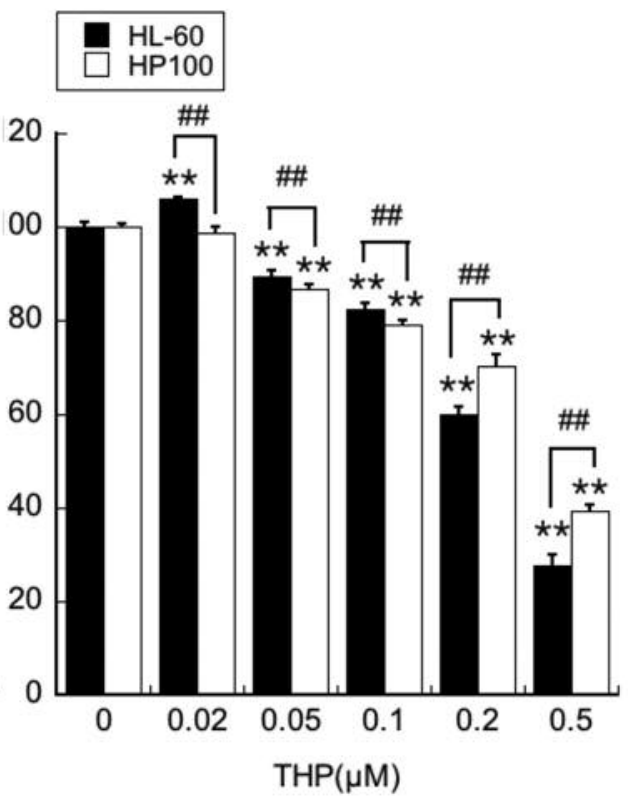

Figure 5. Change of mitochondrial membrane potential $(\Delta \Psi \mathrm{m})$ in HL-60 and HP100 cells treated with THP. HL-60 and HP100 cells $\left(1 \times 10^{6}\right.$

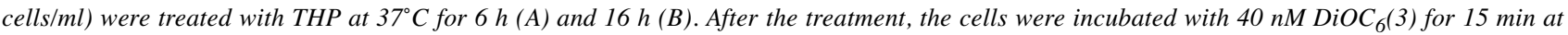
$37^{\circ} \mathrm{C}$. The cells were analyzed with an imaging cytometer (Tali ${ }^{T M}$ Image-based Cytometer; Invitrogen, USA). The data were expressed as means $\pm S D$

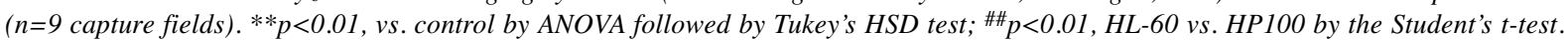

apparent DNA ladder formation could be detected at above $0.2 \mu \mathrm{M}$ after 8 -h incubation and at above $0.1 \mu \mathrm{M}$ after $24-\mathrm{h}$ incubation in HL-60 and HP100 cells, whereas it could be detected at above $0.1 \mu \mathrm{M}$ in HL-60 cells and at above 0.2 $\mu \mathrm{M}$ in HP100 cells after 16-h incubation. In HP100 cells, assessment of THP-induced apoptosis by peroxide generation, $\Delta \Psi \mathrm{m}$ decrease and caspase-3/7 activity were suppressed, compared to those of HL-60 cells. Peroxide formation preceded the apparent cytotoxicity, DNA ladder, caspase-3/7 activation and $\Delta \Psi \mathrm{m}$ decrease in THP-induced apoptosis; in HL-60 cells. The peroxide formation occurred at $3 \mathrm{~h}$ and $6 \mathrm{~h}$ in HL-60 cells, whereas the peroxide formation was suppressed in HP100 cells. It was reported that HP100 cells are about 340-fold more resistant to $\mathrm{H}_{2} \mathrm{O}_{2}$ than the parent cells, HL-60 (15). Therefore, these findings can be explained by the involvement of $\mathrm{H}_{2} \mathrm{O}_{2}$ generation in the THP apoptotic pathway.

It has been considered that the anticancer mechanisms of anthracyclines are due to DNA intercalation, topoisomerase II inhibition and ROS generation (1-3). The DNA intercalation inhibits DNA and RNA synthesis, and results in double-strand DNA breaks (1-3). The topoisomerase II inhibition results in double-strand DNA breaks, and ROS generated by the redox-cycle of anthracyclines cause

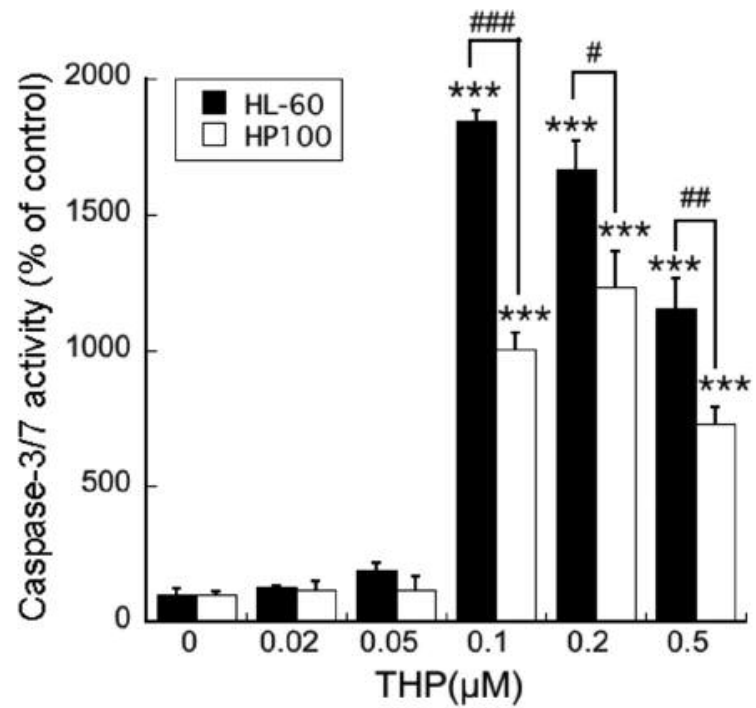

Figure 6. Caspase-3/7 analyses of apoptosis induced by THP in HL-60 and HP100 cells. HL-60 and HP100 cells $\left(0.5 \times 10^{6}\right.$ cells $\left./ \mathrm{ml}\right)$ were treated with THP at $37^{\circ} \mathrm{C}$ for $24 \mathrm{~h}$. After treatment with THP, caspase-3/7 was analyzed by the caspase-3/7 activity assay kit (Apo-ONE ${ }^{\circledR}$ Homogeneous Caspase-3/7 Assay, Promega, USA) according to the manufacturer's instructions. The data were expressed as means $\pm S D(n=3)$. $* * * p<0.001$,

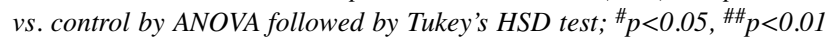
and ${ }^{\# \#} p<0.001, H L-60$ vs. HP100 by the Student's t-test. 


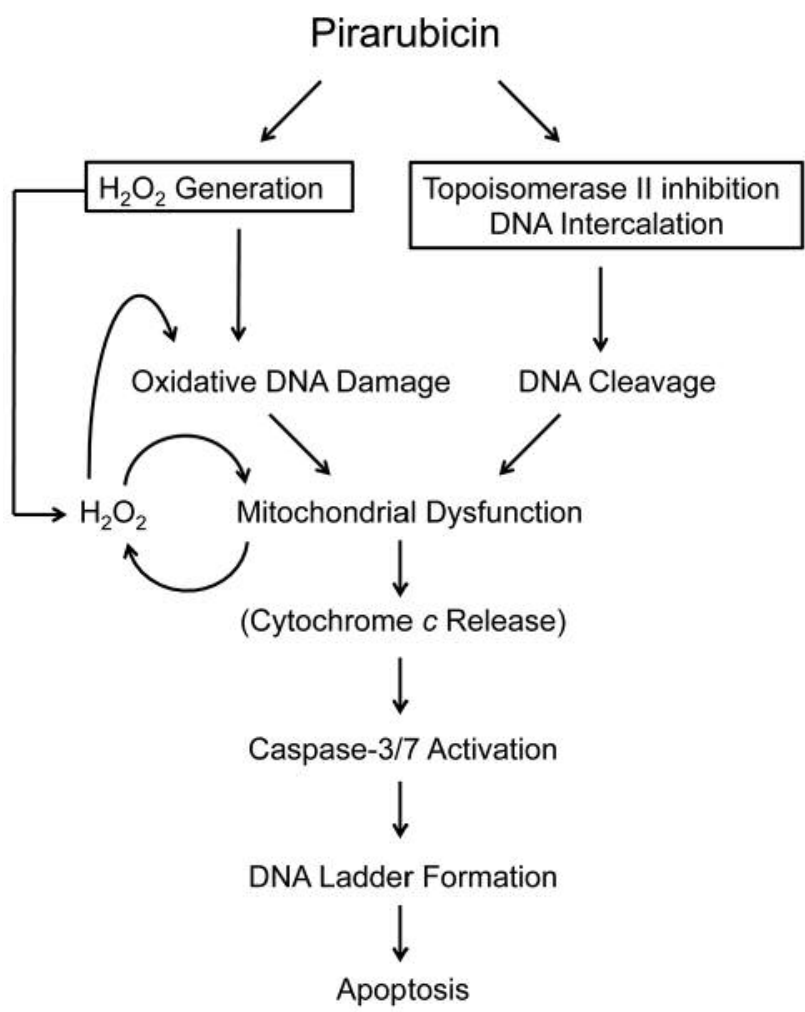

Figure 7. Proposed mechanisms of THP-induced apoptosis via $\mathrm{H}_{2} \mathrm{O}_{2}$ generation.

oxidative DNA damage (1-3). The main mechanism is considered to be the topoisomerase II inhibition, however it is considered that ROS generation is also an important mechanism. We reported that DOX induced apoptosis through $\mathrm{H}_{2} \mathrm{O}_{2}$ generation (22), and also reported that DOX caused site-specific oxidative DNA damage in the presence of copper(II) (23). In addition, many antioxidants attenuate apoptosis and cardiotoxicity induced by anthracyclines (2428). These reports suggest that $\mathrm{H}_{2} \mathrm{O}_{2}$ formation plays important roles in apoptosis induced by anthracyclines. Moreover, mitochondrial dysfunction also induces $\mathrm{H}_{2} \mathrm{O}_{2}$ production that induces more DNA damage (29-31). Thus, we conclude that the apoptotic pathways of DNA damageinduced THP are as follows: THP induces oxidative DNA damage through $\mathrm{H}_{2} \mathrm{O}_{2}$ generation, DNA cleavage through topoisomerase II inhibition and DNA intercalation. Oxidative DNA damage and DNA cleavage cause mitochondrial dysfunction, inducing cytochrome $\mathrm{c}$ release that activates caspase-3/7, leading to apoptosis (Figure 7).

In conclusion, we demonstrated that $\mathrm{H}_{2} \mathrm{O}_{2}$ generation was involved in the THP apoptotic pathway. This $\mathrm{H}_{2} \mathrm{O}_{2}$ generation may be a useful clinical biomarker for anticancer activity or cardiotoxicity of THP in comparison to other anthracyclines. This is the first report on THP-induced apoptosis through $\mathrm{H}_{2} \mathrm{O}_{2}$ generation.

\section{Acknowledgements}

This work was supported by JSPS KAKENHI Grant Number 25460229 and $16 \mathrm{~K} 08420$.

\section{References}

1 Gewirtz DA: A critical evaluation of the mechanisms of action proposed for the antitumor effects of the anthracycline antibiotics adriamycin and daunorubicin. Biochem Pharmacol 57: 727-741, 1999.

2 Minotti G, Menna P, Salvatorelli E, Cairo G and Gianni L: Anthracyclines: molecular advances and pharmacologic developments in antitumor activity and cardiotoxicity. Pharmacol Rev 56: 185-229, 2004.

3 Meredith AM and Dass CR: Increasing role of the cancer chemotherapeutic doxorubicin in cellular metabolism. J Pharm Pharmacol 68: 729-741, 2016.

4 Umezawa H, Takahashi Y, Kinoshita M, Naganawa H, Masuda T, Ishizuka M, Tatsuta $\mathrm{K}$ and Takeuchi T: Tetrahydropyranyl derivatives of daunomycin and adriamycin. J Antibiot (Tokyo) 32: 1082-1084, 1979.

5 Miller AA and Salewski E: Prospects for pirarubicin. Med Pediatr Oncol 22: 261-268, 1994.

6 Tsuruo T, Iida H, Tsukagoshi S and Sakurai Y: 4'-Otetrahydropyranyladriamycin as a potential new antitumor agent. Cancer Res 42: 1462-1467, 1982.

7 Kunimoto S, Miura K, Takahashi Y, Takeuchi T and Umezawa $\mathrm{H}$ : Rapid uptake by cultured tumor cells and intracellular behavior of 4'-O-tetrahydropyranyladriamycin. J Antibiot (Tokyo) 36: 312-317, 1983.

8 Hori H, Kudoh T, Nishimura S, Oda M, Yoshida M, Hara J, Tawa A, Usami I, Tanizawa A, Yumura-Yagi K, Kato K, Kobayashi R, Komada Y, Matsuo K and Horibe K: Acute and late toxicities of pirarubicin in the treatment of childhood acute lymphoblastic leukemia: results from a clinical trial by the Japan Association of Childhood Leukemia Study. Int J Clin Oncol 22: 387-396, 2017.

9 Tsukigawa K, Liao L, Nakamura H, Fang J, Greish K, Otagiri $\mathrm{M}$ and Maeda H: Synthesis and therapeutic effect of styrenemaleic acid copolymer-conjugated pirarubicin. Cancer Sci 106: 270-278, 2015.

10 Nakamura H, Koziolová E, Chytil P, Tsukigawa K, Fang J, Haratake M, Ulbrich K, Etrych T and Maeda H: Pronounced cellular uptake of pirarubicin versus that of other anthracyclines: comparison of HPMA copolymer conjugates of pirarubicin and doxorubicin. Mol Pharm 13: 4106-4115, 2016.

11 Dozono H, Yanazume S, Nakamura H, Etrych T, Chytil P, Ulbrich K, Fang J, Arimura T, Douchi T, Kobayashi H, Ikoma M and Maeda H: HPMA copolymer-conjugated pirarubicin in multimodal treatment of a patient with stage IV prostate cancer and extensive lung and bone metastases. Target Oncol 11: 101-106, 2016.

12 Kalyanaraman B: Teaching the basics of redox biology to medical and graduate students: oxidants, antioxidants and disease mechanisms. Redox Biol 1: 244-257, 2013. 
13 Redza-Dutordoir $M$ and Averill-Bates DA: Activation of apoptosis signalling pathways by reactive oxygen species. Biochim Biophys Acta 1863: 2977-2992, 2016.

14 Galadari S, Rahman A, Pallichankandy S and Thayyullathil F: Reactive oxygen species and cancer paradox: to promote or to suppress? Free Radic Biol Med 104: 144-164, 2017.

15 Kasugai I and Yamada M: Adaptation of human leukemia HL60 cells to hydrogen peroxide as oxidative stress. Leuk Res 13: 757-762, 1989.

16 Kasugai I and Yamada M: High production of catalase in hydrogen peroxide-resistant human leukemia HL-60 cell lines. Leuk Res 16: 173-179, 1992.

17 Russell LH Jr, Mazzio E, Badisa RB, Zhu ZP, Agharahimi M, Oriaku ET and Goodman CB: Autoxidation of gallic acid induces ROS-dependent death in human prostate cancer LNCaP cells. Anticancer Res 32: 1595-1602, 2012.

18 Sakagami H, Sheng H, Okudaira N, Yasui T, Wakabayashi H, Jia J, Natori T, Suguro-Kitajima M, Oizumi H and Oizumi T: Prominent Anti-UV Activity and Possible Cosmetic Potential of Lignin-carbohydrate Complex. In Vivo 30: 331-339, 2016.

19 Mizutani H, Hiraku Y, Tada-Oikawa S, Murata M, Ikemura K, Iwamoto T, Kagawa Y, Okuda M and Kawanishi S: Romidepsin (FK228), a potent histone deacetylase inhibitor, induces apoptosis through the generation of hydrogen peroxide. Cancer Sci 101: 2214-2219, 2010

20 Hiraku Y and Kawanishi S: DNA damage and apoptosis induced by benzene metabolites. Cancer Res 56: 5172-5178, 1996.

21 Lucas BE, Fields C, Joshi N and Hofmann MC: Mono-(2ethylhexyl)-phthalate (MEHP) affects ERK-dependent GDNF signalling in mouse stem-progenitor spermatogonia. Toxicology 299: 10-19, 2012.

22 Mizutani H, Tada-Oikawa S, Hiraku Y, Kojima M and Kawanishi S: Mechanism of apoptosis induced by doxorubicin through the generation of hydrogen peroxide. Life Sci 76: 1439$1453,2005$.

23 Mizutani H, Oikawa S, Hiraku Y, Murata M, Kojima M and Kawanishi S: Distinct mechanisms of site-specific oxidative DNA damage by doxorubicin in the presence of copper(II) and NADPH-cytochrome P450 reductase. Cancer Sci 94: 686-691, 2003.
24 Granados-Principal S, Quiles JL, Ramirez-Tortosa CL, SanchezRovira P and Ramirez-Tortosa MC: New advances in molecular mechanisms and the prevention of adriamycin toxicity by antioxidant nutrients. Food Chem Toxicol 48: 1425-1438, 2010.

$25 \mathrm{Gu} \mathrm{J}, \mathrm{Hu}$ W and Zhang DD: Resveratrol, a polyphenol phytoalexin, protects against doxorubicin-induced cardiotoxicity. J Cell Mol Med 19: 2324-2328, 2015.

26 Angsutararux $\mathrm{P}$, Luanpitpong $\mathrm{S}$ and Issaragrisil $\mathrm{S}$ : Chemotherapy-induced cardiotoxicity: overview of the roles of oxidative stress. Oxid Med Cell Longev 2015: 795602, 2015.

27 Abushouk AI, Ismail A, Salem AMA, Afifi AM and Abdel-Daim MM: Cardioprotective mechanisms of phytochemicals against doxorubicin-induced cardiotoxicity. Biomed Pharmacother 90: 935-946, 2017.

28 Sordillo PP, Sordillo DC and Helson L: The prolonged QT interval: role of pro-inflammatory cytokines, reactive oxygen species and the ceramide and sphingosine-1 phosphate pathways. In Vivo 29: 619-636, 2015.

29 Orrenius S: Reactive oxygen species in mitochondria-mediated cell death. Drug Metab Rev 39: 443-455, 2007.

30 Lee K, Jeong JE, Kim IH, Kim KS and Ju BG: Cyclo(phenylalanine-proline) induces DNA damage in mammalian cells via reactive oxygen species. J Cell Mol Med 19: 2851-2864, 2015.

31 Bagli E, Goussia A, Moschos MM, Agnantis N and Kitsos G: Natural compounds and neuroprotection: mechanisms of action and novel delivery systems. In Vivo 30: 535-547, 2016.
Received June 23, 2017

Revised July 18, 2017

Accepted July 19, 2017 